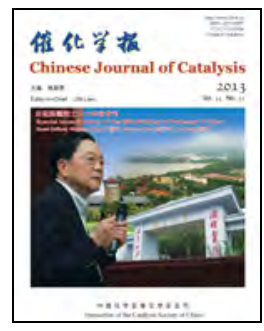

Editorial (Special Issue in Honor of the 80th Birthday of Professor Yi Chen)

\title{
Preface to Special Issue of Chinese Journal of Catalysis in Honor of the 80th Birthday of Professor Yi Chen
}

Professor Yi Chen who was born in 1933 is a renowned physical chemist and educator in China. He has long been engaged in the teaching of physical chemistry and research on heterogeneous catalysis, and the physical chemistry textbooks he wrote with Professor Xiancai Fu has had far-reaching influences on many generations of chemists. He has made many new research findings on the interactions between the constituent components on oxide catalysts and nanoscaled non-crystalline alloy catalysts and in many areas of mesoscopic chemistry. He has published over 400 papers, been granted 26 Chinese and 7 international patents, and been honored with 5 national and provincial academic awards. In 1996, he received the Excellent Academic Leader Award of Jiangsu Province, and his research group received the Excellent Chemistry Group Award of Jiangsu Province. In 1997, he was honored with the National Excellent Scientific and Technological Researcher Award. In 2005, he was elected academician of the Chinese Academy of Sciences.

Professor Yi Chen worked mainly on heterogeneous catalysis in his academic career and achieved notable success. In addition to his teaching and research, he has been very active in promoting the development of catalysis research in China. In the early 1980s, together with Professors Qirui Cai, Shaoyi Peng, Enze Min, and Xiexian Guo, he sat on the national Chinese Catalysis Committee, which was responsible for the organization of catalytic research in China to meet national needs and economic development. He has made many contributions to advance the Chinese catalysis community, including helping to increase international academic exchanges. He was one of the initiators of many international academic conferences, e.g., the First Sino-Japan-USA Conference on Catalysis (1982), which later became the series of International Conference on Catalysis in the Asian-Pacific region. In 2004, on behalf of Chinese Catalysis Committee, he presented the Chinese bid to hold the International Conference on Catalysis in China to the Council of International Association of Catalysis Societies. In 2008, he served as Chairman of the 14th National Conference on Catalysis in China. He has made many definitive contributions in the organization of key research fields to meet national needs, and in the setting up of and development of the 8th and 9th Five Year Initiative (Pangdeng) Projects and National Basic Research Program of China (973 Program). As a member of the academic committees of several key laboratories that work on catalysis, he has devoted much effort to their research planning and academic development. In recent years, he led the long-term collaboration between Nanjing University and SINOPEC and the establishing and development of the Key Laboratory of Mesoscopic Chemistry of the Ministry of Education, which has catalysis as its main research area.

Professor Yi Chen has held many important posts for the development of academic and social communities, e.g., he is a member of the Examining Committee of the Chinese University Development Projects of the World Bank (1982), Committee for the 15-Year Development Plan of Science and Technology in China of the Ministry of Education of China (1983), and Textbook Editorial Committee of Science Departments in Chinese Universities and Colleges, and he has served as Vice Director of the Development Group for Chemistry Curriculum Structuring (1984-1988), Chairman of Chinese Catalysis Committee (1988-1990), Chinese national representative at the International Association of Catalysis Societies (1988-1996), President of Chinese Chemical Society (1994-1998), Director of the Steering Committee for Chemistry Teaching in Chinese Universities and Colleges (1995-2000), member of Science and Technology Committee of the Ministry of Education of China (1990-2000), editorial board member of Journal of Catalysis (2000-2008), member and convener of Chemistry Assessment Group of the Academic Degree Commission of the State Council, and Honorary President of Jiangsu Province Society of Chemistry and Chemical Industry (2005-). In addition, he has served as an Academic Board member for several State Key Laboratories in Chinese universities and Chinese Academy of Sciences.

Professor Yi Chen is a man of enterprise and a high sense of responsibility. He has consistently advocated a learning style of being "rigorous, realistic, diligent and innovative" and personally practices it. During his more than 50 years of teaching and

(C) 2013, Dalian Institute of Chemical Physics, Chinese Academy of Sciences. Published by Elsevier B.V. All rights reserved DOI: 10.1016/S1872-2067(12)60725-6 | http://www.sciencedirect.com/science/journal/18722067 | Chin. J. Catal., Vol. 34, No. 11, November 2013 
research, he has held important leadership positions in the School of Chemistry and Chemical Engineering of Nanjing University. He has done much for the development of Nanjing University, the management and development of chemistry in China, and the reform of Chinese higher education. He has cultivated many talented students and made important contributions to the development of science, technology, and education in China. More details on Professor Yi Chen's life experience, research areas, and academic achievements are available in Brief Biography of Scientific and Technical Experts in China (chemistry volume, science section) compiled by China Association for Science and Technology and published by China Science and Technology Press in 2009.

On the occasion of the 80th birthday of Professor Yi Chen, his students, collaborators, colleagues, and friends have gathered together to publish this special issue in recognition of his outstanding contributions to the development of catalysis and related areas in China. We would like to pay our highest tributes to Professor Yi Chen and sincerely wish him good health and happiness!

We are very grateful to all authors, reviewers, and the editorial staff of the Chinese Journal of Catalysis for their hard work and strong support. May catalysis research in China thrive and prosper!

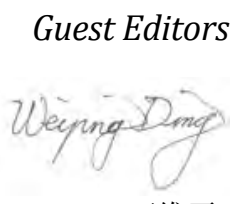

Weiping Ding (丁维平) School of Chemistry and Chemical Engineering, Nanjing University

Nanjing 210093, China E-mail address: dingwp@nju.edu.cn

$$
\text { Weahia Hol }
$$

Wenhua Hou (侯文华) School of Chemistry and Chemical Engineering, Nanjing University Nanjing 210093, China E-mail address: whou@nju.edu.cn

Lin Dong (董林)
School of Chemistry and Chemical Engineering/Center of
Modern Analysis, Nanjing University
Nanjing 210093, China
E-mail address: donglin@nju.edu.cn

Professor Weiping Ding received his BSc in Chemistry from Nanjing University in 1983 and his PhD in Chemistry from Nanjing University in 1992. He was a postdoctoral fellow at the Department of Physics, Nanjing University (1993-1995). He joined the School of Chemistry and Chemical Engineering of Nanjing University in 1996 and was promoted to full professor in 2001. He has served as Vice Dean of the School of Chemistry

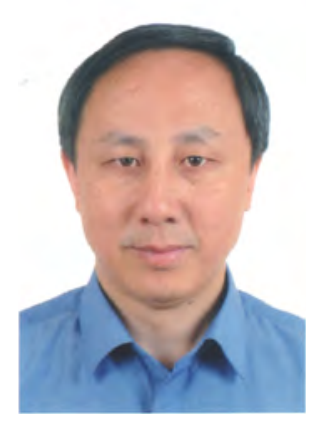

and Chemical Engineering (20082011). He was a visiting scientist at the University of California at Berkeley, USA in 1999-2001, at Harvard University, USA in 2004-2005, at the National University of Singapore in 2013. Currently, he is the Director of the joint research lab of Nanjing University and SINOPEC on catalytic materials and technologies. His research has focused mainly on the development of advanced catalytic materials and applied technologies related to energy chemistry and chemical engineering processes, and recently focused on the development of the novel concepts of meso catalysis and its application in highly selective oxidation, hydrogenation, and solid acid catalyzed conversion of hydrocarbons. His research has pursued high performance and practical catalysts and processes all the time.

Professor Wenhua Hou received

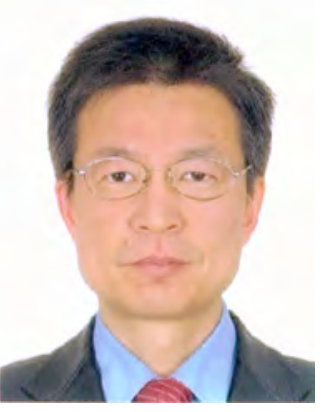
his BSc in 1985, MSc in 1988, and PhD in 1993 in Physical Chemistry from Nanjing University. He was a research assistant in Nanjing Institute of Soil Science, Chinese Academy of Sciences (1988-1990), a visiting scholar at the State University of New York at Albany (1997-1998), and University of California at San Diego (2003). He joined School of Chemistry and Chemical Engineering, Nanjing University in 1993 and became a full professor there in 2000. His research interests include the preparation and catalytic \& electrochemical performances of some novel layered and porous materials, and the fabrication and photoluminescence of nano-/microstructured rare-earth materials. He has published more than 150 papers and won the first- and second-class science and technology progress awards from the State Education Ministry in 2010 and 1999.

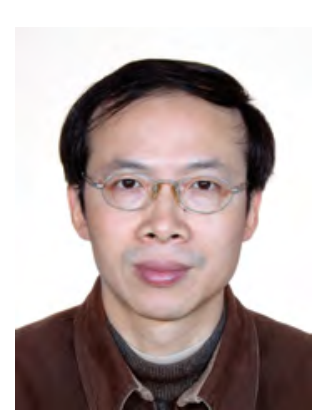

Professor Lin Dong received his BSc in 1984 and MSc in 1987 from South-West Normal University. He obtained his PhD in Physical Chemistry from Nanjing University in 1995. He was a post-doctoral fellow at Catalysis Centre, ESIP, Poitiers University, France (2000-2001, supported by the CNRS K. C. Wong in France). He joined School of Chemistry and Chemical Engineering, Nanjing University in 1997 and became a full professor there in 2002. His current research interests focus on the synthesis of metal-oxide nano-materials and the foundation of the surface interaction of the supported metal-oxide with in-situ characterizations, as well as their applications in the environment protection (especially for $\operatorname{deNO}_{x}, \mathrm{CO}$ oxidation). He has published more than 140 papers and won the second grade prize in science and technology of the Chinese university in 2001. 


\title{
《催化学报》以本期专刊的出版庆祝陈懿先生八十华诞
}

\author{
丁维平, 侯文华, 董 林 \\ 南京大学大学化学化工学院, 江苏南京 210093
}

陈懿(1933-)先生是我国著名物理化学家和教育家, 长期从事物理化学和多相催化的教学与研究工作. 他编 写的《物理化学》和《物理化学》简明本(傅献彩、陈 懿主编, 人民教育出版社, 1961、1965年)等基础课程教 材影响深远. 他在氧化物催化剂组分间相互作用、纳米 非晶合金催化剂以及介观化学等领域取得了丰硕的研 究成果, 发表研究论文400余篇, 获得中国发明专利 26 项, 国际专利 7 项, 获国家和省部级学术奖励 5 项. 1996 年, 陈懿先生被评为江苏省优秀学科带头人, 他领导的 科研组被评为江苏省优秀学科梯队; 1997年被评为全 国优秀科技工作者; 2005年当选为中国科学院院士.

多相催化是陈懿先生的主要研究方向, 他在此领域 浸淫多年, 成果丰硕. 除教学与科研工作外, 他积极推动 中国催化学术研究整体上健康稳定地发展. 1980年代 初参与筹组中国催化委员会, 与蔡启瑞、彭少逸、闵恩 泽、郭学贤等老一辈科学家一起推动中国的催化研究为 国家需求和国民经济发展服务, 为中国催化界走上国际 学术交流平台做了很多重要的工作, 是多种国际催化学 术会议的发起人之一, 参加组织了多届中日美催化会议 (1982年第一届, 两年一次轮流在三国召开), 并推动其 发展为系列的亚太地区国际催化会议(2013年, 第六届). 2004年, 他代表中国催化界在国际催化协会联盟理事会 上做国际催化大会申办报告. 2008年, 他主持了第十四 届全国催化学术大会. 在反映国家需求的重大研究课题 的组织上, 从 “八五”、”九五” 攀登到重大基础研究 规划项目的立项与发展, 他都做出了重要的贡献. 作为 学术委员, 他对国内多家催化相关的重点实验室的研究 规划与学术发展做出了重大贡献. 近年来, 他还主导了 南京大学与中国石化的长期合作实验室以及重在催化 研究的介观化学教育部重点实验室的建立与发展.

此外, 陈懿先生还兼任过多种学术与社会职务, 如
教育部世界银行贷款大学发展项目审议委员(1982), 教 育部编制15年科技发展规划化学组成员(1983), 高校理 科教材编审委员, 化学学科课程结构研究组副组长 (1984-1988), 中国化学会催化专业委员会主任(19881990), 国际催化学会理事中国代表(1988-1996), 中国 化学会理事长(1994-1998), 教育部高等学校化学教学 指导委员会主任(1995-2000), 教育部科技委员会委员 (1990-2000), 国际催化领域权威杂志Journal of Catalysis的编委(2000-2008), 国务院学位委员会化学学科评 议组成员及召集人, 江苏省化学化工学会名誉理事长 (2005-), 作为专家参与制定国家中长期科技发展规划 纲要(2006-2020)等. 此外, 他还兼任多个高校、科学院 的国家重点实验室学术委员会委员.

陈懿先生具有极强的事业心和责任感,一贯倡导继 承和发扬“严谨、求实、勤奋、创新”的学风, 并身体力行. 在五十余载的教学和研究生涯中, 有十多年他先后担任 过南京大学化学系和南京大学主要领导工作, 为南京大 学的发展、我国的化学学科管理与发展以及中国高等教 育改革做了很多实事, 为国家培养了大批人才, 为我国 的科技和教育事业发展做出了积极贡献. 有关陈懿先生 的成长经历、主要研究领域和学术成就请参见中国科技 协会编撰的《中国科学技术专家传略.理学篇化学卷》 (中国科学技术出版社, 2009年出版).

值此陈懿先生八十华诞之际, 他的学生、合作者、 同事和朋友以及仍在多相催化领域努力从事研究工作 的部分同仁作此专刊, 对陈懿先生五十余年来为我国催 化及相关领域发展做出的卓越贡献表示崇高的敬意, 祝 愿他健康快乐.

对于论文作者、审稿专家以及《催化学报》编辑部 等相关人员所付出的辛勤劳动和给予的大力支持, 我们 在此表示衷心感谢, 也祝愿中国催化研究兴旺发达! 